Chapter 8

\title{
Pretreatment of Lignocellulosic Biomass Using Microorganisms: Approaches, Advantages, and Limitations
}

Thomas Canam, Jennifer Town, Kingsley Iroba, Lope Tabil and Tim Dumonceaux

Additional information is available at the end of the chapter

http://dx.doi.org/10.5772/55088

\section{Introduction}

Much of Earth's recent geologic history is dominated by periods of extensive glaciation, with relatively low global mean temperatures and correspondingly low atmospheric $\mathrm{CO}_{2}$ concentrations [1]. The current interglacial period stands out as an anomaly because the atmospheric $\mathrm{CO}_{2}$ concentration has risen sharply above the range of approximately 180-280 parts per million by volume that has defined the past 420,000 years to reach levels that are nearly $40 \%$ higher than the biosphere has experienced over this time frame [2]. This rapid increase in $\mathrm{CO}_{2}$ concentration is primarily due to the release of ancient fixed atmospheric $\mathrm{CO}_{2}$ into the modern atmosphere through the combustion of fossil fuel resources over the past 200 years. Since it is clear from ice core records that atmospheric $\mathrm{CO}_{2}$ concentration has a strong positive correlation to global temperature, it is expected that changes to global climate are forthcoming [3]. There are substantial uncertainties regarding the ability of terrestrial and oceanic carbon sinks to absorb this anthropogenic $\mathrm{CO}_{2}$ on time scales that are relevant to human society [2], so the continued release of ancient $\mathrm{CO}_{2}$ into the modern atmosphere at current rates carries with it an important risk of inducing climate changes of unknown amplitude along with a host of ancillary changes that are difficult to predict with certainty. This has led to the search for alternatives to fossil fuels to meet a rising global energy demand, and one such option is the use of extant organic matter to produce energy. This resource contains carbon that was fixed from the modern atmosphere, which means it does not result in a net increase in atmospheric $\mathrm{CO}_{2}$ upon combustion. 
Meeting the world's energy demands requires resources that are abundant and inexpensive to produce. Biomass from forestry and agricultural activities is certainly a candidate, as hundreds of millions of tonnes of agricultural waste from rice, wheat, corn, and other crops are produced worldwide, which could generate billions of litres of ethanol [4]. For ethanol, butanol, methane, and other biofuels to be produced economically, however, requires an integrated approach, with a number of value-added co-products produced in addition to the energy - a "biorefinery" that stands in analogy to petroleum refineries that produce both energy and a wide range of petroleum-based chemicals and products [5-7]. The biorefinery concept is hardly new, as the industrial-scale bacterial fermentation of starch to acetone and butanol (A-B) was developed a century ago. These A-B fermentations were done on an industrial scale in the West during World War I and persisted into the 1950's. They continued in Russia until late in the Soviet era, ultimately using corn cobs and other agricultural residues as input [8]. However, releasing the energy and co-product potential of plant-based material requires energy inputs and processing steps, as discussed below; this hinders the ability of biofuels to compete economically with petroleum resources, which have been exposed to millions of years of geological energy input to reach their current biochemical state.

Current paradigms for biofuels production include the production of ethanol by yeast or bacteria from glucose produced from soluble sugars and starch $\left(1^{\text {st }}\right.$ generation ethanol $)$ or from the cellulosic fraction of biomass $\left(2^{\text {nd }}\right.$ generation ethanol). Due to a lack of competition with food production, the latter is typically seen as more sustainable on a long-term basis $[9,10]$. An emerging option is the co-production of ethanol and hydrogen via consolidated bioprocessing [11]. In addition to the now little-used anaerobic A-B fermentations discussed above, another scheme for biofuels production from plant biomass involves the anaerobic production of methane by microbial consortia (anaerobic digestion) $[12,13]$. The common link for all of these strategies is the exploitation and optimization of natural microbial activity to produce energy-rich molecules for combustion to produce energy. Direct thermochemical conversion of biomass via pyrolysis or gasification is also possible, although these strategies involve a large amount of energy input by heating the biomass to very high temperatures (normally $>500^{\circ} \mathrm{C}$ ) and are therefore independent of microbial activity [14].

Regardless of the means by which biofuels are produced by microbial activity from extant plant material, the same essential challenge must be faced: the substrate for biofuels production is the carbohydrate fraction, which must be made available to the microorganisms in order for the biochemical reactions to proceed efficiently. In the case of $1^{\text {st }}$ generation ethanol, soluble sugars and starch are relatively easily converted to glucose that is fermented into ethanol by yeast. Strategies that utilize the non-food portion of crops, however, face a more formidable challenge. The resource from which energy is to be produced consists of three major biopolymers: cellulose $(\beta(1,4)$-linked glucose residues with a degree of polymerization up to 15,000$)$; hemicellulose (a heterogeneous, short-chained, branched carbohydrate with both 5- and 6carbon sugars); and lignin (a complex aromatic polymer consisting of nonrepeating covalently linked units of coniferyl, sinapyl, and coumaryl alcohols). These polymers exist together in the plant as a composite, tightly interconnected molecule called lignocellulose [15]. Within lignocellulose, the lignin fraction in particular acts as a barrier to enzyme or microbial 
penetration, which greatly decreases the yields of fermentable sugars and negatively affects the overall process of energy production from these resources to the extent that it is uneconomical $[5,16]$. To overcome this limitation, some form of pretreatment of the biomass is required for economical and efficient production of biofuels by any of the strategies described above [13, 16-21].

The purpose of this chapter is to review the various pretreatment options available for lignocellulosic biomass, with particular emphasis on agricultural residues and on strategies that exploit the natural metabolic activity of microbes to increase the processability of the biomass. These microbial-based strategies can be effective pretreatments on their own or, more probably, can be used in combination with thermomechanical pretreatments in order to provide a cost-effective means to make lignocellulosic substrates available for conversion to biofuels by microorganisms. The key advantages and disadvantages of this strategy will be presented along with a vision for how microbial pretreatment can be integrated into an economical biorefinery process for biofuels and co-product production.

\section{Mechanical, thermomechanical and thermochemical pretreatments}

An early, essential mechanical pretreatment step is comminution, or mechanical particle size reduction, to transform the biomass from its native state into a suitable substrate for further pretreatment and energy production [17]. This step is often not considered in the energy balance of biofuels processes, but it is important to keep in mind that particle size reduction involves energy input that can influence the effective energy yield of these processes [22]. While smaller particle sizes are often considered to be more desirable for yields of fermentable sugars, sizes smaller than about $0.4-0.5 \mathrm{~mm}$ provide no additional benefit $[17,23]$, and the process becomes economically unfeasible at even smaller particle sizes [22]. Methods for mechanical size reduction include wet milling, dry milling, ball milling or vibratory ball milling, and other forms of chipping and grinding of biomass [4, 17]. Regardless of the method employed, particle size reduction requires energy input; therefore, strategies that facilitate the production of biomass in the proper size range while minimizing energy input will provide positive benefits to the overall economics of biofuels processes.

A wide range of options is available for preparing ground biomass for further processing. One of the most common and simple technologies for rendering the carbohydrate fraction available for biofuels production is the application of a dilute solution of sulfuric acid $(0.5 \%-2 \%)$ at temperatures of $140^{\circ} \mathrm{C}-180^{\circ} \mathrm{C}$ with residence times of $10-30$ minutes [24]. This process leaves a residue that is depleted in hemicellulose but retains most of the cellulose intact, making it an ideal substrate for enzymatic hydrolysis to yield fermentable sugars for ethanol production. There is a range of conditions for acid hydrolysis that will result in more or less carbohydrate remaining in the solid fraction, with the most severe conditions used to completely degrade the carbohydrate fraction for the determination of cell wall carbohydrate composition [25]. Harsher conditions (e.g. higher acid concentration and temperature), while resulting in a substrate that is highly digestible with enzymes to generate fermentable sugars, also result in 
a higher yield of compounds derived from pentoses (furfural), hexoses (5-hydroxymethylfurfural) and lignin (low molecular weight phenolic compounds) that are inhibitory to subsequent fermentation by ethanologenic yeasts [26]. The mathematical concept of combined severity, which combines the various factors that define acid hydrolysis conditions (e.g. temperature, residence time, $\mathrm{pH}$ ), allows objective comparisons between different conditions that enables the determination of optimal conditions for a given substrate [26]; however, doubts have been raised about its accuracy [17].

Another highly effective pretreatment strategy is steam explosion, in which biomass is briefly heated to high temperatures $\left(\sim 200^{\circ} \mathrm{C}\right)$ under high pressure, then subjected to a rapid pressure drop that renders the biomass more penetrable by enzymes for subsequent hydrolysis [18]. In some cases, steam explosion is enhanced by the addition of an acid catalyst such as sulfuric acid [27]. For lignocellulosic agricultural residues, steam explosion under optimized conditions has been shown to be an effective pretreatment strategy for enzymatic saccharification [28]. Steam explosion has also been successfully used in combination with other physiochemical pretreatments such as acid/water impregnation of cereal straws [29]. Both of the latter studies resulted in the release of hemicellulose-derived pentose oligomers into the liquid fraction, and it was suggested that the use of ethanologenic strains capable of converting these pentoses into ethanol would further improve overall process efficiency [28]. Other assessments have suggested that the hemicellulose fraction would be more efficiently converted to other value-added products rather than ethanol using post-treatment enzyme addition or further acid hydrolysis [30].

Organosolv is a process by which the lignin fraction is chemically modified and essentially removed from biomass using high-temperature extraction with alcohols such as methanol or ethanol or other solvents, sometimes with dilute acid (e.g. hydrochloric or sulfuric acid) as a catalyst [17]. While organosolv processes require a solvent recovery step to be economical and efficient, they provide a robust means of generating three streams of potential products: an extracted, modified lignin component, a hemicellulose-enriched aqueous phase, and a residue that is highly enriched in cellulose and an excellent substrate for the production of biofuels by enzymatic saccharification followed by bacterial or yeast fermentation. Organosolv is one of the pretreatment options that results in a fraction containing chemically modified, low molecular weight lignin components. This stream has a good deal of product potential in addition to its possible use as a fuel for combustion to provide energy to the process $[7,31]$. While organosolv is particularly suited to very lignin-rich feedstocks such as wood [32], there is increasing interest in using organosolv extractions for agricultural residues such as wheat straw and dedicated biofuels crops [33]. Goh et al. [34] optimized organosolv conditions for empty palm fruit bunch using combined severity calculations, with excellent results and the ability to accurately predict product stream yields.

Microwave pretreatment of biomass is another option that has been reported to improve subsequent enzymatic saccharification of rice straw [35]. Microwaves have the advantage of combining very rapid heating times with a lower energy input than conventional heating strategies. This irradiative pretreatment creates localized hotspots, which open up the lignocellulose composite molecule, thereby facilitating enzyme access for saccharification and 
biofuel production by fermentation [4]. A successful combination of microwave and chemical pretreatments in a microwave-acid-alkali-hydrogen peroxide sequence resulted in efficient enzymatic saccharification of rice straw [36]. A related pretreatment option that has been exploited to improve the enzymatic digestibility of switchgrass is the use of radio frequency heating in combination with alkali; this treatment has the key advantage of allowing a much higher solids content than conventional heating [37]. Irradiation of biomass can also enhance methane production by anaerobic digestion [12].

A number of other pretreatment options exist, including ammonia fiber explosion (AFEX), liquid hot water, alkalai/wet oxidative pretreament, and others; several recent reviews discuss these processes and their advantages and disadvantages in detail [4, 17-20, 23, 30, 38, 39]. Regardless of the strategy employed, a common feature of any pretreatment option is that energy input is required. Pretreatment is a major part of the overall operating expense and energy efficiency of any biofuels process, and, while essential, typically accounts for over $30 \%$ of the costs of biorefinery operation $[40,41]$. Strategies to reduce these costs will have a major impact on the energy balance and economic sustainability of biorefineries.

\section{Biological pretreatments}

Microorganisms have evolved a capacity to modify and access lignocellulosic biomass to meet their metabolic needs. The exploitation of this capacity offers a natural, low-input means for preparing biomass for biofuels processes. Natural modification and degradation of the lignin component in particular can reduce the severity requirements of subsequent thermochemical pretreatment steps. For example, Itoh et al. [42] used a variety of lignin-degrading white-rot fungi to treat wood chips prior to extracting lignin by an organosolv method, and demonstrated that improved ethanol yields were obtained from the solid fraction along with a 15\% savings in electricity use. Similarly, brown-rot fungal species Coniophora puteana and Postia placenta have been successfully used to improve glucose yields upon enzymatic saccharification of pine, acting as a complete replacement for thermomechanical pretreatments [43]. While it is clear that it is possible to exploit the metabolic capabilities of microorganisms to facilitate biofuels production, the very wide taxonomic array of microorganisms that modify or degrade lignocellulose presents a tremendous variety of choices for implementing such a strategy. Each approach carries its own advantages and challenges.

\subsection{Microbial consortia}

One approach for applying the power of microbial metabolism to the challenges of biofuel production involves ensiling, which is a commonly used means for enhancing the digestibility of forage and other biomass for ruminants $[44,45]$. The process of ensiling exploits the capacity of naturally occurring bacteria, mostly Lactobacillaceae, to ferment the sugars within lignocellulosic residues and produce a substrate that is more easily digested by ruminal microorganisms. While these bacterial consortia lack the ability to substantially degrade the lignin component, the changes effected on the biomass can improve yields of fermentable sugars 
upon subsequent enzymatic hydrolysis. For example, ensiling a variety of agricultural residues, including wheat, barley, and triticale straws along with cotton stocks resulted in significant improvements in fermentable carbohydrate yields upon application of cellulosedegrading enzymes [46]. Due to limitations in the ability of ensilage to substantially modify the lignin component, this method is not normally a suitable stand-alone biological pretreatment. However, ensiling has been exploited as a means to preserve biomass for biofuels production and has been found to be a very effective, on-farm biomass pretreatment. A strain of Lactobacillus fermentum was highly effective in preserving sugar beet pulp cellulose and hemicellulose, and ensiling improved enzymatic saccharification by as much as $35 \%$ [47]. Ensiling has also been found to improve yields of methane in anaerobic digestion, with the added benefit of facilitating the longer-term storage of biomass (up to 1 year) while retaining the yield improvements [48, 49]. Improvements in methane yields of up to $50 \%$ have been observed with hemp and maize residue, while other crops showed little improvement [50]. However, other researchers have cautioned that the total solids loss may be overestimated for certain substrates, which may result in a misleading, apparent improvement in methane yields by ensiling [51]. Furthermore, while some studies noted above have shown that desirable carbohydrates can be preserved through ensiling, others have noted degradation of cellulose and hemicellulose of up to $10 \%$ in this relatively uncontrolled, complex process [46]. Nevertheless, ensiling does offer the substantial benefit of biomass preservation and, importantly, it utilizes existing technology and expertise and can be performed on-farm using unmodified farm equipment. Moreover, ensiling is a relatively low-input process that is anaerobic and therefore does not require mixing and aeration. For these reasons, ensiling could easily be incorporated into an overall biorefinery process at the earliest stages of energy production.

\subsection{Lignin-degrading fungi}

The earliest colonization of land by plants began around 450 million years ago. The evolutionary innovation that facilitated their spread and success in the non-marine environment was lignification, which provided protection from ultraviolet radiation, structural rigidity and eventually protection from coevolved pathogens and herbivores [52]. The complexity of the phenylpropanoid polymer also provided a carbon sink as land plants fixed atmospheric $\mathrm{CO}_{2}$ into degradation-resistant lignin. The vast coal reserves whose combustion have contributed to the recent spike in atmospheric $\mathrm{CO}_{2}$ concentrations trace their origins to the Carboniferous period ( 350-300 million years ago), when lignin was not effectively decomposed [52]. Near the end of the Carboniferous period, saprophytic fungi of the class Agaricomycetes evolved the ability to degrade the lignin component of plant biomass, which contributed to a substantial decline in organic carbon burial to the extent that little coal formation occurs today [53, 54]. The large majority of fungal species that are capable of wood decay are known as "white-rot" fungi, which degrade all of the major wood polymers. Approximately $6 \%$ of wood decay species are "brown-rot" fungi, which evolved from white-rot fungi and selectively degrade the cellulose and hemicellulose fraction of wood, leaving a lignin-rich residue that is a major contributor to soil carbon in forest ecosystems [55]. 
The taxonomically broadly distributed white- and brown-rot fungi have developed a variety of means to access and degrade lignocellulose over their long evolutionary history, and their powerful metabolism has been exploited for industrial applications in recent decades. For example, lignin-degrading fungi were noted to have a brightening effect on kraft pulp derived from hardwoods, with savings in bleaching chemicals and potentially decreased environmental impact on paper mill operations [56]. This "biobleaching" was developed further using well-known fungi, such as Trametes versicolor $[57,58]$ and Phanerochaete chrysosporium $[59,60]$. Similar approaches were used to decolorize and detoxify pulp mill effluent and black liquor [61-63]. In addition, white-rot fungi have been exploited for their ability to decrease energy requirements in pulp manufacturing. This process, known as biopulping, softens the woody substrate and substantially decreases mill electricity requirements for mechanical pulp manufacture $[64,65]$. The required scale of industrial pulp manufacture and the applicability of white-rot fungi in providing manufacturing benefits led to the development of feasible means of applying white-rot fungi to biomass on an industrially-relevant scale [66]. This twoauger system featured a wood chip decontamination step and an inoculation step, followed by incubation at ambient temperatures in large chip piles with forced aeration. A series of outdoor trials of this method each featured the treatment of $\sim 36$ tonnes of softwood chips with the biopulping fungus Ceriporiopsis subvermispora for two weeks. The results were energy savings of around 30\% in subsequent pulping, which is slightly higher than was observed in bench-scale trails [66].

\subsubsection{Species and systems investigated}

More recently, wood-degrading fungi have been investigated for their ability to assist in processing biomass for biofuels production. Again, with the tremendous variety of woodrotting species and feedstocks available, there is a wide array of strategies reported for biological pretreatment. One very promising approach used rice straw as feedstock, treated with the white-rot fungus Pleurotus ostreatus (oyster mushroom) followed by AFEX [67]. This strategy resulted in significant reductions in the severity of the required pretreatment along with improved glucose yields upon enzyme treatment - and produced edible mushrooms as a by-product. Another study found that the incubation time required for Pleurotus ostreatus to improve enzymatic saccharification with rice hulls was decreased from 60 days to 18 days by pretreating the rice hulls with hydrogen peroxide prior to fungal inoculation [68]. Similarly, preconditioning of softwood using various white-rot fungi resulted in degradation and modification of the lignin, although significant cellulose loss was also observed [69]. Nevertheless, improved glucose yields were observed by enzymatic saccharification of softwood treated with Stereum hirsutum compared to untreated controls, which was attributed to an increase in the pore size of the substrate [69]. Other studies have exploited the selective lignin degradation ability of the white-rot fungus Echinodontium taxodii to enhance enzymatic saccharification of water hyacinth in combination with dilute acid pretreatment [70], or of woody substrates without subsequent thermochemical pretreatment [71]. Biological pretreament has also been shown to improve biogas yields from agricultural residues via anaerobic digestion [72]. A tremendous variety of other approaches to biological pretreatment has been reported to be successful on many different lignocellulosic substrates [73, 74]. 
Exploitation of fungal metabolic activity for industrial purposes can take a variety of forms. For white- and brown-rot fungi, the mode of cultivation can have an effect on the results obtained, and the choice of cultivation conditions depends on the desired outcomes. In general, fungi can be cultivated under solid-state conditions (solid-state fermentation, or SSF), or using submerged fermentation (SmF). SSF involves culturing the fungus on the substrate under relatively low moisture conditions ( $60-70 \%)$, while $\mathrm{SmF}$ uses liquid cultures of the fungus coincubated with the normally insoluble substrate. Early pulp biobleaching experiments used SmF of white-rot fungi such as Trametes versicolor, which featured the advantage of shorter incubation times than SSF [75], but suffered the drawback that very large fermentation vessels would be required for industrial-scale treatments. Many white-rot fungi grow well and perform the desired metabolism under solid-state conditions. For example, species of the genera Trametes, Phanerochaete, and Pycnoporus preferentially removed color and chemical oxygen demand from olive mill wastewaters and pulp mill black liquors under SSF cultivation conditions [61, 76, 77]. SSF using white-rot fungi has also been used to modify the lignin in agricultural residues, such as wheat straw, for biofuels processes [78].

Despite relatively long incubation times, SSF offers an inexpensive and effective means of fungal cultivation that can also be used for the production of potentially valuable fungal enzymes [79-81]. Fungal enzymes produced by SSF have been used to enhance methane production by anaerobic digestion [82]. Alternatively, fungal lignocellulose modifying enzymes produced by SSF have been used to improve the ruminal digestibility of agricultural residues [83]. However, for SSF to work efficiently with white- or brown-rot fungi requires a decontamination step to allow the fungi to establish on the residues. In lab-scale studies, this is usually accomplished by autoclaving the residues prior to inoculation [84, 85]. While this is necessary at the research scale to establish with certainty the effects of the inoculated fungus on the substrate, autoclaving is in itself a form of pretreatment and is not feasible on an industrial scale. This is a limitation of SSF for application on the large scale that would be required for biological pretreatment of agricultural residues for biofuels production.

\subsubsection{Enzymatic mechanisms of fungal lignocellulose degradation}

The mechanisms that saprophytic wood degrading fungi have evolved to access their difficult growth substrate can be divided into two categories: oxidative mechanisms and hydrolytic mechanisms. These two groups of enzymes and chemicals act together in various combinations to effect the degradation of lignocellulose by different organisms.

\subsubsection{Oxidative mechanisms}

Due to the highly compact, complex nature of lignocellulose, enzymes cannot effectively penetrate this molecule to interact with their substrates. To overcome this limitation, wooddegrading fungi use chemical means to access the recalcitrant substrate. The production of reactive oxygen species (ROS) is a recurring theme in fungal lignocellulose degradation [86]. Specifically, since wood contains sufficient redox-active iron, fungal production of hydrogen peroxide will produce hydroxyl radicals via the Fenton reaction [86]. Hydroxyl radicals $(\bullet \mathrm{OH})$ are extremely powerful oxidizing agents that can catalyze highly non-specific reactions leading 
to the cleavage of covalent bonds in both lignin and cellulose [86]. Hydrogen peroxide is commonly produced through the action of fungal redox enzymes, such as glyoxal oxidase, pyranose-2 oxidase, and aryl-alcohol oxidase [15].

Another redox enzyme produced by a wide variety of wood-degrading fungi (as well as plants) is laccase, a multicopper oxidase. Laccase acts by removing a single electron from its substrate, which is typically a low-molecular weight compound (mediator) that can diffuse into the densely packed lignocellulose molecule and initiate free radical-mediated reactions leading to the depolymerisation of the substrate. The white-rot fungus Pycnoporus cinnabarinus uses laccase in combination with a secondary metabolite, 3-hydroxyanthranilic acid, to effect lignin depolymerisation $[87,88]$. Laccase has been used in combination with a wide variety of chemical mediators to effect lignin degradation in wood pulp, with excellent results [89-91].

The presence of manganese in woody substrates is exploited by lignin-degrading fungi through the production of the enzyme manganese peroxidase $(\mathrm{MnP})$. The importance of $\mathrm{MnP}$ in lignin degradation is illustrated by its presence in the genomes of white-rot fungi and absence in the non-lignin-degrading brown-rot fungi [92], as well as by the inability of $\mathrm{MnP}$ deficient mutants of Trametes versicolor to delignify hardwood-derived kraft pulp [93]. MnP is a heme-containing enzyme with a catalytic cycle that is typical of heme peroxidases, but is uniquely selective for $\mathrm{Mn}^{2+}$ as its preferred electron donor [94]. The oxidation of $\mathrm{Mn}^{2+}$, which is accompanied by the reduction of hydrogen peroxide to water, results in the formation of $\mathrm{Mn}^{3+}$. The latter ion is a powerful, diffusible oxidant that is chelated by organic acids such as oxalate produced as a secondary metabolite of the fungus [94]. This highly reactive ion interacts with a wide variety of substrates, including phenols, non-phenolic aromatics, carboxylic acids, and unsaturated fatty acids, producing further ROS and resulting in lignocellulose bond cleavage through oxidative mechanisms [94]. Like laccase, MnP has found application as a delignifying enzyme for pine wood [95] as well as kraft pulp [96, 97]. Peroxidases related to $\mathrm{MnP}$, including lignin peroxidase (LiP) and versatile peroxidase (VP) are also produced by a variety of wood-degrading fungi and play an important role in lignin degradation [98].

Cellobiose dehydrogenase $(\mathrm{CDH})$ is a unique enzyme containing both a heme and a flavin cofactor [99]. $\mathrm{CDH}$ is produced by a wide range of fungal species, including both lignindegrading organisms and fungi that are incapable of degrading lignin [100, 101]. CDH catalyzes the two-electron oxidation of a narrow range of $\beta(1,4)$-linked sugar molecules, principally cellobiose, and transfers these electrons to a very wide array of substrates, including metals such as ferric, cupric, or manganic ions, iron-containing proteins (e.g. cytochrome c), quinones, and other large and small molecules [102,103]. The diversity of reduced substrates has led to much speculation regarding the role of $\mathrm{CDH}$ in lignocellulose degradation; roles have been postulated in the degradation of both cellulose [104] and lignin [105]. The reduction of cupric and ferric ions by $\mathrm{CDH}$ and the production of hydrogen peroxide by lignin-degrading fungi suggests that $\mathrm{CDH}$ may be involved in sustaining hydroxyl radical-based Fenton's chemistry, with many possible secondary reactions leading to lignocellulose bond cleavage [106]. The role of $\mathrm{CDH}$ in lignin-degrading basidiomycetes was addressed by generating mutants of Trametes versicolor that did not produce the enzyme, suggesting that CDH plays a role in cellulose degradation, with a more minor role in lignin degradation $[107,108]$. Similarly, 
a recent study with the non- lignin-degrading ascomycete Neurospora crassa revealed that deletion of the gene encoding $\mathrm{CDH}$ resulted in vastly decreased cellulase activity, and that the oxidation of cellobiose was coupled to the reductive activation of copper-containing polysaccharide monooxygenases [109]. These studies strongly suggest a role for CDH in supporting cellulose catabolism by fungi, with the latter study in particular providing a highly plausible mechanism for the in vivo function of $\mathrm{CDH}$.

\subsubsection{Hydrolytic mechanisms}

Complementing the degradative power of the redox chemistry catalyzed by the enzymes produced by lignocellulose-degrading fungi is a suite of enzymes that act by adding a water molecule to glycosidic bonds, resulting in bond cleavage and depolymerization. In contrast to the redox enzymes, these hydrolytic enzymes recognize and act on specific glycosidic linkages, releasing sugar molecules that can be utilized as an energy source to support fungal metabolism. Cellulose degradation is catalyzed by the synergistic action of three classes of hydrolytic cellulase enzymes: endo-(1,4)- $\beta$-glucanase (endocellulase), cellobiohydrolase (exocellulase), and $\beta$-glucosidase [110]. Endocellulases catalyze the cleavage of cellulose chains internally at amorphous regions, while exocellulases remove cellobiose units from the ends of cellulose chains. $\beta$-glucosidases are extracellular, cell wall-associated or intracellular enzymes that cleave cellobiose into glucose, which also supports exocellulase activity by relieving endproduct inhibition [110]. The redundancy in cellulase genes in fungi is at least partially explained by the fact that different exocellulase enzymes preferentially attack the reducing or non-reducing end of a cellulose chain. This has the effect of exposing new sites for exocellulases of the opposite specificity and also generates new amorphous regions to be acted upon by endocellulases $[110,111]$. Hemicellulose degradation is effected by the activity of a wide range of hydrolytic enzymes, including endo-xylanases; endo- $\alpha$-L-arabinase; endo-mannanase, $\beta$ galactosidase, and an array of corresponding $\beta$-glucosidases [112]. In addition, covalent bonds within lignocellulose are hydrolyzed by cinnamoyl or feruloyl esterases, which cleave the ester bond between polymerized lignin subunits and the hemicellulose within the composite molecule $[113,114]$. Complementary cellulase activity by these various "accessory enzymes" is shown on complex substrates by the improvement in enzymatic saccharification observed when enzymes such as xylanase, pectinase, and feruloyl esterase are added to cellulase cocktails $[115,116]$.

\subsubsection{Fungal enzyme discovery, production, and application}

Tremendous progress has been made in the last decade concerning the genetic mechanisms underlying plant biomass degradation and modification by microbes, specifically ascomycetous and basidiomycetous fungi. Key to these advancements was the complete genome sequencing of several biomass-degrading fungi, including Phanerochaete chrysosporium, Phanerochaete carnosa, Postia placenta and Trametes versicolor. The first basidiomycete genome to be sequenced and analyzed, Phanerochaete chrysosporium, revealed a tremendous diversity of genes encoding enzymes involved in wood degradation [117]. Among these genes were approximately 240 carbohydrate-active enzymes and several lignin and manganese-depend- 
ent peroxidases, which function to degrade the cellulosic/hemicellulosic and lignin components of the cell wall, respectively. This research provided the groundwork for more comprehensive analyses of the genome [118], transcriptome and secretome of Phanerochaete chrysosporium [119-122]. These studies highlighted hundreds of wood-degrading genes that were upregulated when $P$. chrysosporium was grown in cellulose-rich medium, including almost 200 genes encoding enzymes of unknown function [122].

Complementary to this research on white-rot fungi was a genome/transcriptome/proteome study on the brown-rot fungus Postia placenta [123]. Despite an abundance of similarities between $P$. chrysosporium and $P$. placenta, there were notably fewer glycoside hydrolases expressed by $P$. placenta, such as extracellular cellulases (e.g. endo-(1,4)- $\beta$-glucanases), highlighting the mechanistic differences between white- and brown-rot fungi. This work was followed by transcriptomic and proteomic studies investigating the biomass-degrading activity of Phanerochaete carnosa [124, 125]. Despite the overall similarity of the transcriptome composition among $P$. carnosa and $P$. chrysosporium, the most abundant transcripts in $P$. carnosa grown on wood substrates (hardwood and softwood) were peroxidases and oxidases involved in lignin degradation [124], whereas P. chrysosporium grown only on hardwood revealed only a few highly expressed lignin-degrading enzymes [121]. The differing expression of lignocellulosic enzymes in response to different woody substrates was also explored by examining gene expression patterns in both $P$. placenta and $P$. chrysosporium on hardwood and softwood species [126]. The results of this study strongly suggest that both species of fungi alter their gene expression patterns to degrade wood with different structural characteristics.

In addition to helping uncover the fundamental biochemical machinery involved in biomass degradation, these genomic, transcriptomic and proteomic studies of biomass-degrading fungi have also identified hundreds of target enzymes that could be utilized industrially for bioenergy production, with unique enzyme cocktails suited for specific substrates (e.g. hardwoods vs. softwoods). Several commercial enzymes are commonly used to degrade lignocellulosic residue into fermentable sugars (e.g. Celluclast and Novozyme 188). These 'omic' studies have identified hundreds of fungal glycoside hydrolases that may supplement or completely replace these industry standards. Pre-treatment strategies may also take advantage of the numerous lignin-modifying enzymes identified from biomass-degrading fungi, including lignin and manganese-dependent peroxidases, which have the potential to reduce the severity of thermomechanical and thermochemical pretreatment processes.

\subsubsection{Exploiting fungal mutants for biological pretreatment}

The explosion of 'omic' data for a wide variety of lignocellulose-degrading fungi [117, 123-125] along with the development of sophisticated tools for annotating fungal genomes [127] will continue to add to our understanding of the mechanisms of fungal decay of lignocellulose. Furthermore, increased knowledge of fungal decay mechanisms can aid in the development of strains with improved characteristics. For example, a major limitation to the application of fungal strains for biological pretreatment is the degradation of the desired carbohydrates (cellulose and hemicellulose) for fungal metabolism [73, 74]. Creating or selecting strains that lack the ability to degrade these carbohydrates while retaining the ability to degrade and 
modify lignin would provide a means to avoid this drawback of fungal pretreatment. Early studies with strains that were deficient in the production of cellulase met with only moderate success, with substantial degradation of cellulose observed [128, 129]. This is probably attributable to the high degree of redundancy in fungal cellulases, with large numbers of genes contributing to the hydrolytic degradation of cellulose and hemicellulose in various species [15]. More recently, we have applied a strain of Trametes versicolor that is unable to produce cellobiose dehydrogenase $(\mathrm{CDH})$ to the pretreatment of canola residue, and found that the strain was proficient in lignin degradation but was unable to catabolize the cellulose [107]. Xylose within the substrate appeared to have been utilized to support the greatly decreased fungal growth compared to the wild-type strain. Furthermore, we found that the application of a fungal cell wall-degrading enzyme cocktail (glucanex; a concentrated supernatant of a SmF culture of Trichoderma harzianum) to the fungus-treated biomass resulted in the release of fungal cell wall-associated glucose [107]. Biological pretreatment with T. versicolor therefore had the overall effect of converting some of the xylose within the substrate to glucose, which is more easily fermented by ethanologenic yeasts.

Studies such as these also provide biological data regarding the role of the genes that are downregulated in the mutant strains. This reverse genetics approach is a powerful method for investigating gene function, and in the current genomic era reverse genetics tools can often be applied in the known context of the entire genome of the fungus. Gene silencing by RNA interference (RNAi) is a common method for down-regulating genes in a variety of model systems [130,131], and the recent demonstration of RNAi mechanisms in the model white-rot fungus Phanerochaete chrysosporium [132] suggests that RNAi could be used for targeted downregulation of specific genes in species that are useful for biological pretreatment. The availability of convenient gene silencing transformation vectors for ascomycetes such as pSilent [133] and pTroya [134] as well as pHg/pSILBA $\gamma$ for basidiomycetes [135] will greatly facilitate the investigation of gene function and may also result in the development of modified strains featuring enhanced properties for biological pretreatment of lignocellulosic substrates for biofuels production.

\section{Conclusions and future outlook}

Pretreatment of lignocellulosic materials with white- or brown-rot fungi can be incorporated into any strategy for the production of biofuels and bioproducts, with significant advantages including decreased energy requirements for subsequent steps, production of fewer fermentation-inhibiting substances, and the potential for the production of value-added co-product streams $[73,74]$. With the wide variety of potential strains and substrates available, and the possibility to create or select new strains with more desirable properties, it seems likely that biological pretreatment can be used on nearly any biomass that is currently produced. One of the most important benefits of biological pretreatment is the resultant reduction in the severity of the subsequent thermomechanical or thermochemical pretreatment step that is required for efficient enzymatic saccharification. While this is a very important benefit, Keller et al. [136] identified six criteria for strains to be selected for biological pretreatment of agricultural waste: 
little carbohydrate degradation, low costs for nutrients, a reasonable storage time, ability to compete with endogenous microbiota, decreased thermomechanical pretreatment severity, improved yields of glucose upon enzymatic saccharification, and a lack of production of compounds inhibitory to fermenting organisms. These criteria underscore the major limitations of biological pretreatment, the most important of which are the propensity of the organisms to degrade the carbohydrate component, their inability to establish growth on unsterilized biomass, and the relatively long incubation times that are required. These limitations are related to the ecological niche that these saprophytic fungi fill in nature. That is, they have evolved to access and utilize those plant carbohydrates that are difficult for other microorganisms to access. For this reason, these fungi typically appear at the end of an ecological succession of organisms that degrade decaying wood and are often ill equipped to compete with the faster-growing molds and bacteria that access the more easily degraded plant carbohydrates [137]. While it may be possible using reverse genetics tools and/or strain selection to limit carbohydrate degradation by pretreatment fungi [107], it is likely that such strains will be even less able to compete with endogenous microorganisms; therefore, establishment on recently harvested biomass will remain a challenge. Some sort of treatment of the biomass to suppress the growth of endogenous molds prior to inoculation with the pretreatment fungi will likely be necessary.

The unavoidable expense of the pre-inoculation treatment can be compensated by taking advantage of a potential benefit of biological pretreatment that has received very little attention: wood-degrading fungimay modify thelignin componentsufficiently to providepositivebenefits for particle compression of agricultural biomass during densification. Densification (briquetting or pelleting) of biomass aims to increase the bulk density of agricultural residues far beyond what is achievable by baling, and it is an essential step for providing biomass with sufficient caloric density for efficient transportation [138]. The production of biomass pellets provides a substrate that is suitable for conversion into biofuels through microbial processes or gasification [139,140], or can be combusted directly to produceenergy [141]. A wide variety of agricultural feedstocks is suitable for pelleting [142]; however, untreated biomass is very difficult to densify and, without pretreatment, produces weak, powdery pellets that are expensive to produce and cannotwithstand thephysicalrigorsoftransportation. Ligninactsasanaturalbinderthat provides strength and durability to biomass pellets, and pretreatment of the biomass is required in order to release lignin fragments during compaction and produce pellets with the desired characteristics $[139,143]$. A number of options are available to prepare biomass for pelleting, with two very promisingmethodsbeing microwaveheating and radiofrequencyheating. Bothof thesemethods provide a number of advantages over conventional heating, particularly regarding treatment times [144-146]. We have found that a very brief microwave treatment of a variety of agricultural feedstocks suppresses the grow th of endogenous molds and bacteria sufficiently for inoculated white-rot fungi to establish growth on these substrates. Moreover, canola residue treated with Trametes versicolor produces pellets with excellent compaction characteristics and durability (Canam, Town, and Dumonceaux, unpublished). Such pellets would retain the thermochemical pretreatment benefits afforded by the fungal pretreatment in terms of enzymatic saccharification [107], but would offer vastly increased transportation efficiency in a full-scale biorefinery scenario. 
A

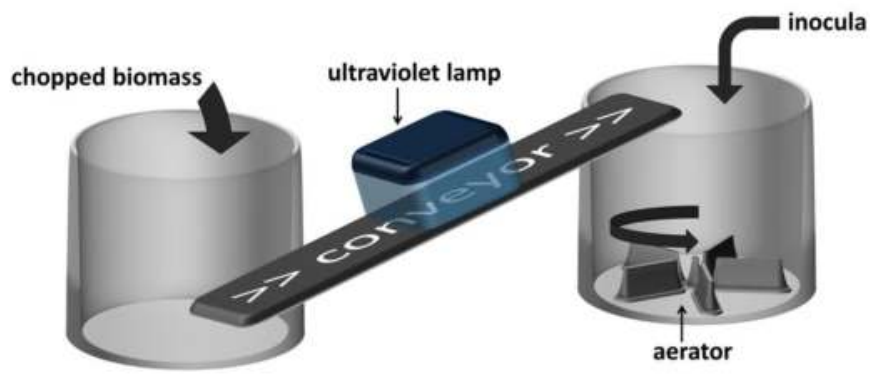

B

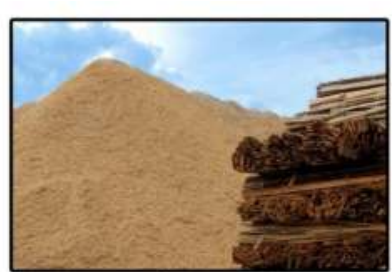

1. biomass harvesting

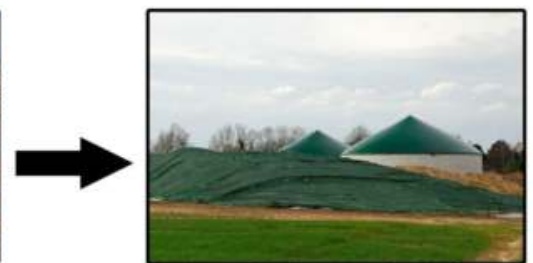

2. inoculation and ensilage
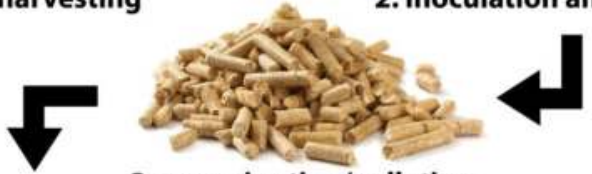

3. comminution/pelleting

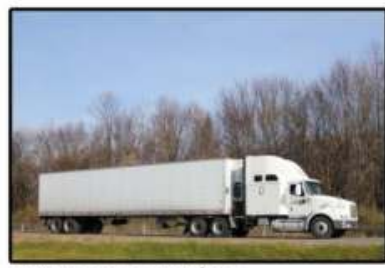

4. transportation

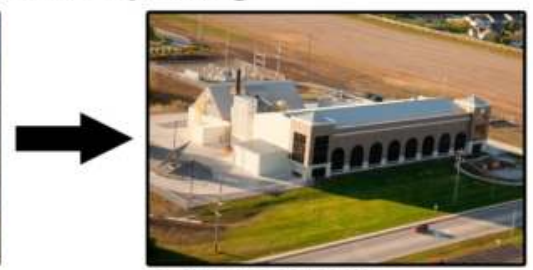

5. bioprocessing

Figure 1. A possible scheme for incorporating biological pretreatment into biofuels manufacturing. A. Treatment to suppress the growth of endogenous microorganisms to allow establishment of the inoculated fungal culture. A variety of treatments could be utilized, including ultraviolet, microwave, or radio frequency treatment. This scheme is based on the successful biopulping inoculation strategy described by Scott et al. [66] B. Overall scheme for biofuels production including biological pretreatment. (B.5. photo courtesy of Jay Grabiec, Eastern Illinois University).

We can therefore envision a means by which fungal pretreatment might be incorporated into an overall process for producing energy from biomass by a variety of strategies (Figure 1). Biological pretreatment should be included at the earliest stages in order to take maximum advantage of its beneficial effects. Building on the successful bio-pulping model described by Scott et al. [66], chopped biomass would be briefly decontaminated by microwave or radio frequency heating within a conveyor; the objective of this is not sterilization or complete 
thermal pretreatment of the biomass, but primarily growth suppression of endogenous microbiota. The lightly treated biomass would then be inoculated with a fungal suspension or formulation and transferred via auger to a pile analogous to a silage pile, but with aeration. The inoculated biomass would be incubated at ambient temperatures for several weeks to allow fungal growth. The fully infested biomass would then be milled to an appropriate size using standard equipment. After cooling and/or drying, pellets formed from the milled, pretreated biomass would be suitable for transport to a biorefinery for biofuels/bioproducts manufacture. In the absence of a viable product stream or a biorefinery, biomass pellets could be burned in a high-efficiency oven to exploit their calorific value [139]. Biological pretreatment would provide an array of benefits along this production chain, including decreased milling energy, decreased compression energy requirements, improved densification characteristics and the consequent reduction in transportation cost, decreased severity of thermochemical pretreatments, decreased production of fermentation inhibitors, improved yield of fermentable sugars upon enzymatic saccharification, and possibly co-products derived from the more easily extractable lignin phase. All of these benefits would be realized with a fairly minor energy input, and although it is difficult to avoid the long incubation times, SSF can be performed on time scales only slightly longer than the common on-farm practice of ensilage. Biological pretreatments can therefore, in theory, be performed on-farm or nearby, offering significant logistical and technical advantages when incorporated into an overall process for biofuels manufacture.

\section{Author details}

Thomas Canam ${ }^{1}$, Jennifer Town ${ }^{2,3}$, Kingsley Iroba ${ }^{4}$, Lope Tabil ${ }^{4}$ and Tim Dumonceaux ${ }^{2,3^{*}}$

*Address all correspondence to: tim.dumonceaux@agr.gc.ca

1 Department of Biological Sciences, Eastern Illinois University, Charleston, IL, USA

2 Agriculture and Agri-Food Canada Saskatoon Research Centre, Saskatoon, Canada

3 Department of Veterinary Microbiology, University of Saskatchewan, Saskatoon, Canada

4 Department of Chemical and Biological Engineering, University of Saskatchewan, Saskatoon, Canada

\section{References}

[1] Wolff EW. Greenhouse gases in the Earth system: A palaeoclimate perspective. Philosophical Transactions of the Royal Society A: Mathematical, Physical and Engineering Sciences. 2011;369(1943):2133-47. 
[2] Falkowski P, Scholes RJ, Boyle E, Canadell J, Canfield D, Elser J, et al. The Global Carbon Cycle: A Test of Our Knowledge of Earth as a System. Science. 2000;290(5490):291-6.

[3] Crowley TJ. Causes of climate change over the past 1000 years. Science. 2000;289(5477):270-7.

[4] Sarkar N, Ghosh SK, Bannerjee S, Aikat K. Bioethanol production from agricultural wastes: An overview. Renewable Energy. 2012;37(1):19-27.

[5] Menon V, Rao M. Trends in bioconversion of lignocellulose: Biofuels, platform chemicals \& biorefinery concept. Progress in Energy and Combustion Science. 2012;38(4): 522-50.

[6] Ragauskas AJ, Williams CK, Davison BH, Britovsek G, Cairney J, Eckert CA, et al. The path forward for biofuels and biomaterials. Science. 2006;311(5760):484-9.

[7] Sannigrahi P, Pu Y, Ragauskas A. Cellulosic biorefineries-unleashing lignin opportunities. Curr Opin Environ Sustain. 2010;2(5-6):383-93.

[8] Zverlov VV, Berezina O, Velikodvorskaya GA, Schwarz WH. Bacterial acetone and butanol production by industrial fermentation in the Soviet Union: Use of hydrolyzed agricultural waste for biorefinery. Appl Microbiol Biotechnol. 2006;71(5): 587-97.

[9] Rude MA, Schirmer A. New microbial fuels: a biotech perspective. Curr Opin Microbiol. 2009;12(3):274-81.

[10] Khanna M, Hochman G, Rajagopal D, Sexton S, Zilberman D. Sustainability of food, energy and environment with biofuels. CAB Reviews: Perspectives in Agriculture, Veterinary Science, Nutrition and Natural Resources. 2009;4(28).

[11] Carere CR, Sparling R, Cicek N, Levin DB. Third generation biofuels via direct cellulose fermentation. Int J Molec Sci. 2008;9(7):1342-60.

[12] Chandra R, Takeuchi H, Hasegawa T. Methane production from lignocellulosic agricultural crop wastes: A review in context to second generation of biofuel production. Renewable and Sustainable Energy Reviews. 2012;16(3):1462-76.

[13] Frigon JC, Guiot SR. Biomethane production from starch and lignocellulosic crops: A comparative review. Biofuels, Bioproducts and Biorefining. 2010;4(4):447-58.

[14] Bahng MK, Mukarakate C, Robichaud DJ, Nimlos MR. Current technologies for analysis of biomass thermochemical processing: A review. Analytica Chimica Acta. 2009;651(2):117-38.

[15] Martinez AT, Ruiz-Duenas FJ, Martinez MJ, Del Rio JC, Gutierrez A. Enzymatic delignification of plant cell wall: from nature to mill. Curr Opin Biotechnol. 2009;20(3): 348-57. 
[16] Margeot A, Hahn-Hagerdal B, Edlund M, Slade R, Monot F. New improvements for lignocellulosic ethanol. Curr Opin Biotechnol. 2009;20(3):372-80.

[17] Agbor VB, Cicek N, Sparling R, Berlin A, Levin DB. Biomass pretreatment: Fundamentals toward application. Biotechnol Adv. 2011;29(6):675-85.

[18] Chandra RP, Bura R, Mabee WE, Berlin A, Pan X, Saddler JN. Substrate pretreatment: the key to effective enzymatic hydrolysis of lignocellulosics? Adv Biochem Eng Biotechnol. 2007;108:67-93.

[19] Conde-Mejía C, Jiménez-Gutiérrez A, El-Halwagi M. A comparison of pretreatment methods for bioethanol production from lignocellulosic materials. Process Safety and Environmental Protection.

[20] Hendriks ATWM, Zeeman G. Pretreatments to enhance the digestibility of lignocellulosic biomass. Bioresour Technol. 2009;100(1):10-8.

[21] Kumar P, Barrett DM, Delwiche MJ, Stroeve P. Methods for pretreatment of lignocellulosic biomass for efficient hydrolysis and biofuel production. Industrial and Engineering Chemistry Research. 2009;48(8):3713-29.

[22] da Costa Sousa L, Chundawat SP, Balan V, Dale BE. 'Cradle-to-grave' assessment of existing lignocellulose pretreatment technologies. Curr Opin Biotechnol. 2009;20(3): $339-47$.

[23] Chang VS, Burr B, Holtzapple MT. Lime pretreatment of switchgrass. Appl Biochem Biotechnol. 1997;63-65:3-19.

[24] Yang B, Lu Y, Wyman CE. Cellulosic ethanol from agricultural residues. In: Balscheck HP, Ezeji TC, Scheffran J, editors. Biofuels from Agricultural Wastes and Byproducts. Ames, Iowa: Wiley-Blackwell; 2010. p. 175-200.

[25] Sluiter A, Hames B, Ruiz R, Scarlata C, Sluiter J, Templeton D, et al. Determination of structural carbohydrates and lignin in biomass. NREL/TP-510-4261. 2008.

[26] Larsson S, Palmqvist E, Hahn-Hägerdal B, Tengborg C, Stenberg K, Zacchi G, et al. The generation of fermentation inhibitors during dilute acid hydrolysis of softwood. Enz Microb Technol. 1999;24(3-4):151-9.

[27] Ballesteros I, Negro MJ, Oliva JM, Cabanas A, Manzanares P, Ballesteros M. Ethanol production from steam-explosion pretreated wheat straw. Appl Biochem Biotechnol. 2006;129-132:496-508.

[28] Ruiz E, Cara C, Manzanares P, Ballesteros M, Castro E. Evaluation of steam explosion pre-treatment for enzymatic hydrolysis of sunflower stalks. Enz Microb Technol. 2008;42(2):160-6.

[29] Rosgaard L, Pedersen S, Meyer AS. Comparison of different pretreatment strategies for enzymatic hydrolysis of wheat and barley straw. Appl Biochem Biotechnol. 2007;143(3):284-96. 
[30] Carvalheiro F, Duarte LC, GÃrio FM. Hemicellulose biorefineries: A review on biomass pretreatments. Journal of Scientific and Industrial Research. 2008;67(11):849-64.

[31] Doherty WOS, Mousavioun P, Fellows CM. Value-adding to cellulosic ethanol: Lignin polymers. Industrial Crops and Products. 2011;33(2):259-76.

[32] Bozell JJ, Black SK, Myers M, Cahill D, Miller WP, Park S. Solvent fractionation of renewable woody feedstocks: Organosolv generation of biorefinery process streams for the production of biobased chemicals. Biomass Bioenergy. 2011;35:4197-208.

[33] Buranov AU, Mazza G. Lignin in straw of herbaceous crops. Industrial Crops and Products. 2008;28(3):237-59.

[34] Goh CS, Tan HT, Lee KT, Brosse N. Evaluation and optimization of organosolv pretreatment using combined severity factors and response surface methodology. Biomass Bioenergy. 2011;35(9):4025-33.

[35] Ma H, Liu WW, Chen X, Wu YJ, Yu ZL. Enhanced enzymatic saccharification of rice straw by microwave pretreatment. Bioresour Technol. 2009;100(3):1279-84.

[36] Zhu S, Wu Y, Yu Z, Wang C, Yu F, Jin S, et al. Comparison of three microwave/chemical pretreatment processes for enzymatic hydrolysis of rice straw. Biosys Engin. 2006;93(3):279-83.

[37] Hu Z, Wang Y, Wen Z. Alkali (NaOH) pretreatment of switchgrass by radio frequency-based dielectric heating. Appl Biochem Biotechnol. 2008;148(1-3):71-81.

[38] Khanal SK, Rasmussen M, Shrestha P, Van Leeuwen H, Visvanathan C, Liu H. Bioenergy and biofuel production from wastes/residues of emerging biofuel industries. Wat Envrion Res. 2008;80(10):1625-47.

[39] Zhang X, Tu M, Paice MG. Routes to potential bioproducts from lignocellulosic biomass lignin and hemicelluloses. Bioenergy Res. 2011;4(4):246-57.

[40] Lynd LR. Overview and evaluation of fuel ethanol from cellulosic biomass: Technology, economics, the environment, and policy. Annu Rev Energy Environ. 1996;21(1): 403-65.

[41] Lynd LR, Elander RT, Wyman CE. Likely features and costs of mature biomass ethanol technology. Appl Biochem Biotechnol. 1996;57-58:741-61.

[42] Itoh H, Wada M, Honda Y, Kuwahara M, Watanabe T. Bioorganosolve pretreatments for simultaneous saccharification and fermentation of beech wood by ethanolysis and white rot fungi. J Biotechnol. 2003;103(3):273-80.

[43] Ray MJ, Leak DJ, Spanu PD, Murphy RJ. Brown rot fungal early stage decay mechanism as a biological pretreatment for softwood biomass in biofuel production. Biomass Bioenergy. 2010;34(8):1257-62. 
[44] McEniry J, O'Kiely P, Clipson NJW, Forristal PD, Doyle EM. Bacterial community dynamics during the ensilage of wilted grass. J Appl Microbiol. 2008;105(2):359-71.

[45] Thompson DN, Barnes JM, Houghton TP. Effect of additions on ensiling and microbial community of senesced wheat straw. Appl Biochem Biotechnol. 2005;121(1-3): 21-46.

[46] Chen Y, Sharma-Shivappa RR, Chen C. Ensiling agricultural residues for bioethanol production. Appl Biochem Biotechnol. 2007;143(1):80-92.

[47] Zheng Y, Yu C, Cheng YS, Zhang R, Jenkins B, VanderGheynst JS. Effects of ensilage on storage and enzymatic degradability of sugar beet pulp. Bioresour Technol. 2011;102(2):1489-95.

[48] Herrmann C, Heiermann M, Idler C. Effects of ensiling, silage additives and storage period on methane formation of biogas crops. Bioresour Technol. 2011;102(8): 5153-61.

[49] Nizami AS, Korres NE, Murphy JD. Review of the integrated process for the production of grass biomethane. Environmental Science and Technology. 2009;43(22): 8496-508.

[50] Pakarinen A, Maijala P, Jaakkola S, Stoddard F, Kymäläinen M, Viikari L. Evaluation of preservation methods for improving biogas production and enzymatic conversion yields of annual crops. Biotechnol Biofuels. 2011;4(20).

[51] Kreuger E, Nges I, Björnsson L. Ensiling of crops for biogas production: Effects on methane yield and total solids determination. Biotechnol Biofuels. 2011;4(44).

[52] Weng JK, Chapple C. The origin and evolution of lignin biosynthesis. New Phytologist. 2010;187(2):273-85.

[53] Floudas D, Binder M, Riley R, Barry K, Blanchette RA, Henrissat B, et al. The paleozoic origin of enzymatic lignin decomposition reconstructed from 31 fungal genomes. Science. 2012;336(6089):1715-9.

[54] Hittinger CT. Evolution: Endless rots most beautiful. Science. 2012;336(6089):1649-50.

[55] Eastwood DC, Floudas D, Binder M, Majcherczyk A, Schneider P, Aerts A, et al. The plant cell wall-decomposing machinery underlies the functional diversity of forest fungi. Science. 2011;333(6043):762-5.

[56] Kirk TK, Yang HH. Partial delignification of unbleached kraft pulp with ligninolytic fungi. Biotechnol Lett. 1979;1(9):347-52.

[57] Roy BP, Archibald F. Effects of kraft pulp and lignin on Trametes versicolor carbon metabolism. Appl Environ Microbiol. 1993;59(6):1855-63.

[58] Selvam K, Saritha KP, Swaminathan K, Manikandan M, Rasappan K, Chinnaswamy P. Pretreatment of wood chips and pulp with Fomes lividus and Trametes versicolor 
to reduce chemical consumption in paper industries. Asian J Microbiol Biotechnol Environ Sci. 2006;8(4):771-6.

[59] Jiménez L, López F, Martínez C. Biological pretreatments for bleaching wheat-straw pulp. Process Biochem. 1994;29(7):595-9.

[60] Jiménez L, Martínez C, Pérez I, López F. Biobleaching procedures for pulp from agricultural residues using Phanerochaete chrysosporium and enzymes. Process Biochem. 1997;32(4):297-304.

[61] Da Re V, Papinutti L. Black liquor decolorization by selected white-rot fungi. Appl Biochem Biotechnol. 2011;165(2):406-15.

[62] Kumar A, Shrivastava V, Pathak M, Singh RS. Biobleaching of pulp and paper mill effluent using mixed white rot fungi. Biosci Biotechnol Res Asia. 2010;7(2):925-31.

[63] Mittar D, Khanna PK, Marwaha SS, Kennedy JF. Biobleaching of pulp and paper mill effluents by Phanerochaete chrysosporium. J Chem Technol Biotechnol. 1992;53(1): 81-92.

[64] Scott GM, Akhtar M, Kirk TK, editors. An Update on Biopulping Commericialization. Proceedings of the 2000 TAPPI Pulping/Process and Product Quality Process; 2000; Boston, MA.

[65] Sena-Martins G, Almeida-Vara E, Moreira PR, Polónia I, Duarte JC, editors. Biopulping of pine wood chips for production of kraft paper board. Proceedings of the 2000 TAPPI Pulping/Process and Product Quality Process; 2000; Boston, MA.

[66] Scott GM, Akhtar M, Lentz MJ, Kirk TK, Swaney R. New technology for papermaking: Commercializing biopulping. Tappi J. 1998;81(11):220-5.

[67] Balan V, Da Costa Sousa L, Chundawat SPS, Vismeh R, Jones AD, Dale BE. Mushroom spent straw: A potential substrate for an ethanol-based biorefinery. J Ind Microbiol Biotechnol. 2008;35(5):293-301.

[68] Yu J, Zhang J, He J, Liu Z, Yu Z. Combinations of mild physical or chemical pretreatment with biological pretreatment for enzymatic hydrolysis of rice hull. Bioresour Technol. 2009;100(2):903-8.

[69] Lee JW, Gwak KS, Park JY, Park MJ, Choi DH, Kwon M, et al. Biological pretreatment of softwood Pinus densiflora by three white rot fungi. J Microbiol. 2007;45(6): 485-91.

[70] Ma F, Yang N, Xu C, Yu H, Wu J, Zhang X. Combination of biological pretreatment with mild acid pretreatment for enzymatic hydrolysis and ethanol production from water hyacinth. Bioresour Technol. 2010;101(24):9600-4.

[71] Yu H, Guo G, Zhang X, Yan K, Xu C. The effect of biological pretreatment with the selective white-rot fungus Echinodontium taxodii on enzymatic hydrolysis of softwoods and hardwoods. Bioresour Technol. 2009;100(21):5170-5. 
[72] Muthangya M, Mshandete AM, Kivaisi AK. Two-stage fungal pre-treatment for improved biogas production from sisal leaf decortication residues. Int J Molec Sci. 2009;10(11):4805-15.

[73] Isroi, Millati R, Syamsiah S, Niklasson C, Cahyanto MN, Lundquist K, et al. Biological pretreatment of lignocelluloses with white-rot fungi and its applications: A review. BioResources. 2011;6(4):5224-59.

[74] Chen S, Zhang X, Singh D, Yu H, Yang X. Biological pretreatment of lignocellulosics: potential, progress and challenges. Biofuels. 2010;1(1):177-99.

[75] Paice MG, Archibald FS, Bourbonnais R, Jurasek L, Reid ID, Charles T, et al. Enzymology of kraft pulp bleaching by Trametes versicolor. In: Jeffries TW, Viikari L, editors. Enzymes for Pulp and Paper Processing. Washington: American Chemical Society; 1996. p. 151-64.

[76] Alaoui SM, Merzouki M, Penninckx MJ, Benlemlih M. Relationship between cultivation mode of white rot fungi and their efficiency for olive oil mill wastewaters treatment. Elec J Biotechnol. 2008;11(4).

[77] Aloui F, Abid N, Roussos S, Sayadi S. Decolorization of semisolid olive residues of "alperujo" during the solid state fermentation by Phanerochaete chrysosporium, Trametes versicolor, Pycnoporus cinnabarinus and Aspergillus niger. Biochem Engin J. 2007;35(2):120-5.

[78] Dinis MJ, Bezerra RMF, Nunes F, Dias AA, Guedes CV, Ferreira LMM, et al. Modification of wheat straw lignin by solid state fermentation with white-rot fungi. Bioresour Technol. 2009;100(20):4829-35.

[79] Rodríguez Couto S, Moldes D, Liébanas A, Sanromán A. Investigation of several bioreactor configurations for laccase production by Trametes versicolor operating in solid-state conditions. Biochem Engin J. 2003;15(1):21-6.

[80] Rodríguez Couto S, Sanromán MA. Application of solid-state fermentation to ligninolytic enzyme production. Biochem Engin J. 2005;22(3):211-9.

[81] Winquist E, Moilanen U, Mettälä, A., Leisola M, Hatakka A. Production of lignin modifying enzymes on industrial waste material by solid-state cultivation of fungi. Biochem Engin J. 2008;42(2):128-32.

[82] Bochmann G, Herfellner T, Susanto F, Kreuter F, Pesta G. Application of enzymes in anaerobic digestion. 2007. p. 29-35.

[83] Graminha EBN, GonÃßalves AZL, Pirota RDPB, Balsalobre MAA, Da Silva R, Gomes E. Enzyme production by solid-state fermentation: Application to animal nutrition. Anim Feed Sci Technol. 2008;144(1-2):1-22.

[84] Kuhar S, Nair LM, Kuhad RC. Pretreatment of lignocellulosic material with fungi capable of higher lignin degradation and lower carbohydrate degradation improves 
substrate acid hydrolysis and the eventual conversion to ethanol. Can J Microbiol. 2008;54(4):305-13.

[85] Rasmussen ML, Shrestha P, Khanal SK, Pometto Iii AL, van Leeuwen J. Sequential saccharification of corn fiber and ethanol production by the brown rot fungus Gloeophyllum trabeum. Bioresour Technol. 2010;101(10):3526-33.

[86] Hammel KE, Kapich AN, Jensen Jr KA, Ryan ZC. Reactive oxygen species as agents of wood decay by fungi. Enz Microb Technol. 2002;30(4):445-53.

[87] Eggert C, Temp U, Dean JF, Eriksson KE. A fungal metabolite mediates degradation of non-phenolic lignin structures and synthetic lignin by laccase. FEBS Lett. 1996;391(1-2):144-8.

[88] Eggert C, Temp U, Eriksson KE. Laccase is essential for lignin degradation by the white-rot fungus Pycnoporus cinnabarinus. FEBS Lett. 1997 Apr 21;407(1):89-92.

[89] Bajpai P, Anand A, Bajpai PK. Bleaching with lignin-oxidizing enzymes. Biotechnology Annual Review2006. p. 349-78.

[90] Bourbonnais R, Paice MG. Enzymatic delignification of kraft pulp using laccase and a mediator. Tappi J. 1996;79(6):199-204.

[91] Call HP, Mucke I. History, overview and applications of mediated lignolytic systems, especially laccase-mediator-systems (Lignozym ${ }^{\circledR}-$ process). J Biotechnol. 1997;53(2-3): 163-202.

[92] Ruiz-Duenas F, Martınez A. Microbial degradation of lignin: How a bulky recalcitrant polymer is efficiently recycled in nature and how we can take advantage of this. Microb Biotechnol. 2009;2:164-77.

[93] Addleman K, Dumonceaux T, Paice MG, Bourbonnais R, Archibald FS. Production and characterization of Trametes versicolor mutants unable To bleach hardwood kraft pulp. Appl Environ Microbiol. 1995 10;61(10):3687-94.

[94] Hofrichter M. Review: Lignin conversion by manganese peroxidase (MnP). Enz Microb Technol. 2002;30(4):454-66.

[95] Hofrichter M, Lundell T, Hatakka A. Conversion of milled pine wood by manganese peroxidase from Phlebia radiata. Appl Environ Microbiol. 2001;67(10):4588-93.

[96] Feijoo G, Moreira MT, Alvarez P, Lú-Chau TA, Lema JM. Evaluation of the enzyme manganese peroxidase in an industrial sequence for the lignin oxidation and bleaching or eucalyptus kraft pulp. J Appl Polymer Sci. 2008;109(2):1319-27.

[97] Paice MG, Reid ID, Bourbonnais R, Archibald FS, Jurasek L. Manganese peroxidase, produced by Trametes versicolor during pulp bleaching, demethylates and delignifies kraft pulp. Appl Environ Microbiol. 1993;59(1):260-5. 
[98] Hammel KE, Cullen D. Role of fungal peroxidases in biological ligninolysis. Curr Opin Plant Biol. 2008;11(3):349-55.

[99] Henriksson G, Johansson G, Pettersson G. A critical review of cellobiose dehydrogenases. J Biotechnol. 2000;78(2):93-113.

[100] Harreither W, Sygmund C, Augustin M, Narciso M, Rabinovich ML, Gorton L, et al. Catalytic properties and classification of cellobiose dehydrogenases from Ascomycetes. Appl Environ Microbiol. 2011;77(5):1804-15.

[101] Zamocky M, Ludwig R, Peterbauer C, Hallberg BM, Divne C, Nicholls P, et al. Cellobiose dehydrogenase - A flavocytochrome from wood-degrading, phytopathogenic and saprotropic fungi. Curr Protein Peptide Sci. 2006;7(3):255-80.

[102] Henriksson G, Ander P, Pettersson B, Pettersson G. Cellobiose dehydrogenase (cellbiose oxidase) from Phanerochaete chrysosporium as a wood degrading enzyme. Studies on cellulose, xylan and synthetic lignin. Appl Microbiol Biotechnol. 1995;42(5):790-6.

[103] Roy BP, Dumonceaux T, Koukoulas AA, Archibald FS. Purification and characterization of cellobiose dehydrogenases from the white rot fungus Trametes versicolor. Appl Environ Microbiol. 1996 12;62(12):4417-27.

[104] Mansfield SD, De Jong E, Saddler JN. Cellobiose dehydrogenase, an active agent in cellulose depolymerization. Appl Environ Microbiol. 1997;63(10):3804-9.

[105] Roy BP, Paice MG, Archibald FS, Misra SK, Misiak LE. Creation of metal-complexing agents, reduction of manganese dioxide, and promotion of manganese peroxidasemediated Mn(III) production by cellobiose:quinone oxidoreductase from Trametes versicolor. J Biol Chem. 1994;269(31):19745-50.

[106] Mason MG, Nicholls P, Wilson MT. Rotting by radicals--the role of cellobiose oxidoreductase? Biochem Soc Trans. 2003;31(Pt 6):1335-6.

[107] Canam T, Town JR, Tsang A, McAllister TA, Dumonceaux TJ. Biological pretreatment with a cellobiose dehydrogenase-deficient strain of Trametes versicolor enhances the biofuel potential of canola straw. Bioresour Technol. 2011;102:10020-7.

[108] Dumonceaux T, Bartholomew K, Valeanu L, Charles T, Archibald F. Cellobiose dehydrogenase is essential for wood invasion and nonessential for kraft pulp delignification by Trametes versicolor. Enz Microb Technol. 2001;29(8-9):478-89.

[109] Phillips CM, Beeson WT, Cate JH, Marletta MA. Cellobiose dehydrogenase and a copper-dependent polysaccharide monooxygenase potentiate cellulose degradation by Neurospora crassa. ACS Chem Biol. 2011 Dec 16;6(12):1399-406.

[110] Baldrian P, Valaskova V. Degradation of cellulose by basidiomycetous fungi. FEMS Microbiol Rev. 2008;32(3):501-21. 
[111] Gilkes NR, Kwan E, Kilburn DG, Miller RC, Warren RAJ. Attack of carboxymethylcellulose at opposite ends by two cellobiohydrolases from Cellulomonas fimi. J Biotechnol. 1997;57(1-3):83-90.

[112] Shallom D, Shoham Y. Microbial hemicellulases. Curr Opin Microbiol. 2003;6(3): 219-28.

[113] Crepin VF, Faulds CB, Connerton IF. Functional classification of the microbial feruloyl esterases. Appl Microbiol Biotechnol. 2004;63(6):647-52.

[114] Mathew S, Abraham TE. Ferulic acid: An antioxidant found naturally in plant cell walls and feruloyl esterases involved in its release and their applications. Crit Rev Biotechnol. 2004;24(2-3):59-83.

[115] Berlin A, Gilkes N, Kilburn D, Bura R, Markov A, Skomarovsky A, et al. Evaluation of novel fungal cellulase preparations for ability to hydrolyze softwood substrates Evidence for the role of accessory enzymes. Enz Microb Technol. 2005;37(2):175-84.

[116] Berlin A, Maximenko V, Gilkes N, Saddler J. Optimization of enzyme complexes for lignocellulose hydrolysis. Biotechnol Bioengin. 2007;97(2):287-96.

[117] Martinez D, Larrondo LF, Putnam N, Gelpke MD, Huang K, Chapman J, et al. Genome sequence of the lignocellulose degrading fungus Phanerochaete chrysosporium strain RP78. Nat Biotechnol. 2004 Jun;22(6):695-700.

[118] Vanden Wymelenberg A, Minges P, Sabat G, Martinez D, Aerts A, Salamov A, et al. Computational analysis of the Phanerochaete chrysosporium v2.0 genome database and mass spectrometry identification of peptides in ligninolytic cultures reveal complex mixtures of secreted proteins. Fungal Genet Biol. 2006;43(5):343-56.

[119] Abbas A, Koc H, Liu F, Tien M. Fungal degradation of wood: initial proteomic analysis of extracellular proteins of Phanerochaete chrysosporium grown on oak substrate. Curr Genet. 2005;47(1):49-56.

[120] Ravalason H, Jan G, Mollé D, Pasco M, Coutinho P, Lapierre C, et al. Secretome analysis of Phanerochaete chrysosporium strain CIRM-BRFM41 grown on softwood. Appl Microbiol Biotechnol. 2008;80(4):719-33.

[121] Sato S, Feltus F, Iyer P, Tien M. The first genome-level transcriptome of the wooddegrading fungus Phanerochaete chrysosporium grown on red oak. Curr Genet. 2009;55(3):273-86.

[122] Vanden Wymelenberg A, Gaskell J, Mozuch M, Kersten P, Sabat G, Martinez D, et al. Transcriptome and secretome analyses of Phanerochaete chrysosporium reveal complex patterns of gene expression. Appl Environ Microbiol. 2009 June 15, 2009;75(12): 4058-68.

[123] Martinez D, Challacombe J, Morgenstern I, Hibbett D, Schmoll M, Kubicek CP, et al. Genome, transcriptome, and secretome analysis of wood decay fungus Postia placen- 
ta supports unique mechanisms of lignocellulose conversion. Proc Natl Acad Sci USA. 2009 February 10, 2009;106(6):1954-9.

[124] MacDonald J, Doering M, Canam T, Gong Y, Guttman DS, Campbell MM, et al. Transcriptomic responses of the softwood-degrading white-rot fungus Phanerochaete carnosa during growth on coniferous and deciduous wood. Appl Environ Microbiol. 2011;77(10):3211-8.

[125] MacDonald J, Master ER. Time-dependent profiles of transcripts encoding lignocellulose-modifying enzymes of the white rot fungus Phanerochaete carnosa grown on multiple wood substrates. Appl Environ Microbiol. 2012 March 1, 2012;78(5): 1596-600.

[126] Vanden Wymelenberg A, Gaskell J, Mozuch M, Splinter BonDurant S, Sabat G, Ralph $\mathrm{J}$, et al. Significant alteration of gene expression in wood decay fungi Postia placenta and Phanerochaete chrysosporium by plant species. Appl Environ Microbiol. 2011;77(13):4499-507.

[127] Levasseur A, Piumi F, Coutinho PM, Rancurel C, Asther M, Delattre M, et al. FOLy: an integrated database for the classification and functional annotation of fungal oxidoreductases potentially involved in the degradation of lignin and related aromatic compounds. Fungal Genet Biol. 2008 May;45(5):638-45.

[128] Karunanandaa K, Fales SL, Varga GA, Royse DJ. Chemical composition and biodegradability of crop residues colonized by white-rot fungi. J Sci Food Agric. 1992;60(1):105-12.

[129] Akin DE, Sethuraman A, Morrison WH, III, Martin SA, Eriksson KEL. Microbial delignification with white rot fungi improves forage digestibility. Appl Environ Microbiol. 1993;59(12):4274-82.

[130] Mahmood ur R, Ali I, Husnain T, Riazuddin S. RNA interference: The story of gene silencing in plants and humans. Biotechnol Adv. 2008;26(3):202-9.

[131] Nakayashiki H, Nguyen QB. RNA interference: roles in fungal biology. Curr Opin Microbiol. 2008;11(6):494-502.

[132] Matityahu A, Hadar Y, Dosoretz CG, Belinky PA. Gene silencing by RNA interference in the white rot fungus Phanerochaete chrysosporium. Appl Environ Microbiol. 2008;74(17):5359-65.

[133] Nakayashiki H, Hanada S, Nguyen BQ, Kadotani N, Tosa Y, Mayama S. RNA silencing as a tool for exploring gene function in ascomycete fungi. Fungal Genet Biol. 2005;42(4):275-83.

[134] Shafran H, Miyara I, Eshed R, Prusky D, Sherman A. Development of new tools for studying gene function in fungi based on the Gateway system. Fungal Genet Biol. 2008;45(8):1147-54. 
[135] Kemppainen MJ, Pardo AG. pHg/pSILBA $\gamma$ vector system for efficient gene silencing in homobasidiomycetes: Optimization of ihpRNA - Triggering in the mycorrhizal fungus Laccaria bicolor. Microb Biotechnol. 2010;3(2):178-200.

[136] Keller FA, Hamilton JE, Nguyen QA. Microbial pretreatment of biomass: potential for reducing severity of thermochemical biomass pretreatment. Appl Biochem Biotechnol. 2003;105 -108:27-41.

[137] Lakovlev A, Stenlid J. Spatiotemporal patterns of laccase activity in interacting mycelia of wood-decaying basidiomycete fungi. Microb Ecol. 2000;39(3):236-45.

[138] Panwar V, Prasad B, Wasewar KL. Biomass residue briquetting and characterization. J Eng Engineering. 2011;137(2):108-14.

[139] Granada E, López González LM, Míguez JL, Moran J. Fuel lignocellulosic briquettes, die design and products study. Renewable Energy. 2002;27(4):561-73.

[140] Kaliyan N, Morey RV. Natural binders and solid bridge type binding mechanisms in briquettes and pellets made from corn stover and switchgrass. Bioresour Technol. 2010;101(3):1082-90.

[141] Alaru M, Kukk L, Olt J, Menind A, Lauk R, Vollmer E, et al. Lignin content and briquette quality of different fibre hemp plant types and energy sunflower. Field Crops Res. 2011;124(3):332-9.

[142] Karunanithy C, Wang Y, Muthukumarappan K, Pugalendhi S. Physiochemical Characterization of Briquettes Made from Different Feedstocks. Biotechnol Res Int. 2012;2012:165202.

[143] Adapa PK, Tabil LG, Schoenau GJ. Compression characteristics of non-treated and steam-exploded barley, canola, oat, and wheat straw grinds. Appl Engin Agric. 2010;26(4):617-32.

[144] Ramaswamy H, Tang J. Microwave and radio frequency heating. Food Sci Technol International. 2008;14(5):423-7.

[145] Iroba K, Tabil L, editors. Densification of radio frequency pretreated lignocellulosic biomass barley straw. ASABE Annual International Meeting; 2012; St. Joseph, MI, USA: American Society of Agricultural and Biological Engineers.

[146] Kashaninejad M, Tabil LG. Effect of microwave-chemical pre-treatment on compression characteristics of biomass grinds. Biosys Engin. 2011;108(1):36-45. 